\title{
The exploitation of western and southern deserts in Iraq for the production of solar energy
}

\author{
Ahmed Z. Abass, D. A. Pavlyuchenko \\ Industrial Power Supply Systems, Novosibirsk State Technical University, Russia
}

\begin{tabular}{l}
\hline \hline Article Info \\
\hline Article history: \\
Received Aug 1, 2018 \\
Revised Apr 17, 2019 \\
Accepted Jun 26, 2019
\end{tabular}

Keywords:

Air pollutants

Exploitation of desert

Iraqi desert

Photovoltaic systems

Renewable energies

Solar density

\begin{abstract}
We have, an overview is presented of the potential future demands and possible supply of solar energy to Iraq. Solar energy, which is clean, unlimited, and environmentally friendly, is presented as a renewable energy resource. Many problems such as $\mathrm{CO}_{2}$ emissions, industry, human activities, and electricity distribution grids have attracted much attention because of the current state of crude oil production and its prices. Moreover, estimations of solar radiation levels and of the efficiencies of photovoltaics (PVs), concentrated solar power (CSP), and solar chimney towers, have all been investigated. Those systems that combine various sources of energy are called hybrids and they have received much attention in recent decades. The basic features of solar radiation in Iraq are outlined, and the selection of those sites with potential for development of solar plants is based on the local largest solar radiation. Moreover, longitudinal and latitudinal orientation, wind, solar intensity, dust, temperature, rain, humidity, and pollution factors are all considered in the calculation of PV/CSP efficiencies. We know there is an abundance of fossil fuels in Iraq, energy shortages began in 1991 because of the perturbation caused by the full ruin of the country. The obvious renewable energy resource available in Iraq is the solar energy, and its exploitation would provide a means to reduce $\mathrm{CO}_{2}$ emissions from the burning of fossil fuels and to achieve self-sufficiency of electric energy and export the rest to neighboring countries. Solar energy is becoming increasingly important because of the climatic change in the form of global warming.
\end{abstract}

Copyright $\odot 2019$ Institute of Advanced Engineering and Science. All rights reserved.

\section{Corresponding Author:}

Ahmed Z. Abass,

Industrial Power Supply Systems,

Novosibirsk State Technical University,

20, Prospekt K. Marksa, Novosibirsk, 630073, Russia.

Email: theking.amir@mail.ru

\section{INTRODUCTION}

Since 1980 until today, Iraq has been in a continuous war and has destroyed all the infrastructure. In 1980, the Iran-Iraq war started, which continued for eight years. This war caused an increase in government spending on war and reduced spending on infrastructure, especially electricity. In 1991, the first Gulf War sparked when the US-British-French coalition launched the worst campaign in human history to destroy all infrastructures. This brutal aggression targeted all the country's power plants indiscriminately and caused over 95\% destruction at all stations. After this war and the destruction of this country, the United States and its allies from the coalition countries imposed resolutions through the United Nations the blockade of Iraq and expose its citizens of starvation and causing severe shortages of food and medicine and continued this siege until the invasion of Iraq in 2003 and occupation by the aggressor countries headed by United State. 
All these unjust acts of aggression have destroyed the infrastructure of Iraq's power plants. Today, in 2018, Iraq still suffers from a severe shortage in the processing of electricity to citizens, noting that $90 \%$ of the factories and government buildings are still out of work. The demand for electricity in Iraq increased from $11000 \mathrm{MW}$ in 2007 to $16000 \mathrm{MW}$ in 2013, to $24500 \mathrm{MW}$ in summer 2018, and is expected that this demand will be increased to more than $30000 \mathrm{MW}$ in 2020 [1].

The Iraqi Ministry of Electricity has identified the shortage in the production of electricity up to $6000 \mathrm{MW}$ increasing during the summer because of the need to use air conditioners in this hot season of the year, which runs from May until the end of September [2]. The bulk of the country's citizens rely on small or medium-sized generators (not more than one megawatts) to compensate for the lack of government processing. These generators work with Iraqi gasoline and diesel, which both represent the worst fuels in the world because they contain large amounts of sulfur that meaning more and more pollution. The operation of these generators causes high noise as well as the emission of millions of tons of air pollutants and greenhouse gases. It is believed that the several generators operating in Iraq exceeded two million generators of all sizes. The use of renewable energies in Iraq is still very late and does not exceed some of the dams that produce hydroelectric power and some shy projects to use photovoltaic (PV) systems whose capacity does not exceed $10 \mathrm{~kW}$.

The Iraqi government should use solar energy to produce electricity as one of its future goals as part of its focus on reducing environmental damage and pollution of the country's atmosphere, soil, and water as well as working to find the best ways to use renewable energy in the country. Solar energy is a clean energy which has the potential to meet a significant proportional of the world's energy needs. It can be broadly classified into two systems; photovoltaic (PV) energy system which converts solar energy into electrical energy, and thermal energy system which converts solar energy into thermal energy. The PV is one of the technology used to harness solar energy[3]. The availability of renewable energy sources locally and renewable, in addition to being environmentally friendly, is one of the most important factors determining the choice of new sources of energy. It can be said that solar energy in Iraq meets all these requirements. The level of solar energy density in this country is very high and among the desirable rates globally where it exceeds in some areas $2200 \mathrm{kWh} / \mathrm{m}^{2} /$ year. As it is free energy for all, renewable for a long time, and does not harm the environment. The Iraqi government should invest in renewable energies by means of the large revenues from oil sales and the exploitation of the great desert lands, which is considered one of the best places in the world in terms of the number of hours of sunrise and estimated about 3300 hours during the year as well as the amount of radiation on it. To cover the deficit in the production of electric power, which is about $6000 \mathrm{MW}$ currently, we prepare for a plan that takes about 6 to 8 years and over these years possible to establish solar plants to cover the current deficit and future increase. The Iraqi government owns a lot of empty land which can be allocated or offered to invest in the field of setting up solar plants. We know that the construction of solar fields does not take as much time as other electric stations, where it is possible to build a station with a capacity of $500 \mathrm{MW}$ in one year, for example in China started in 2013 the biggest solar photovoltaic station (Longyangxia Dam Solar Park) was built with a nameplate capacity of 320 MWp (Phase I), covering 9 square kilometres (3.5 sq mi). An additional $530 \mathrm{MWp}$ (Phase II) was completed in 2015, covering further 14 square kilometres [4], and India soon reclaimed this with the launch of its 1000 MW Kurnool Ultra Mega Solar Park in Andhra Pradesh. Spread over 23 square kilometres, this solar park was operational by May 2017 and by October, had already generated over 800 million units of energy and saved over 700,000 tonnes of $\mathrm{CO}_{2}$, where construction took more than two and a half years [5].

\section{SOLAR ENERGY PERSPECTIVES IN IRAQ}

Countries in the Arabian Peninsula have not adopted solar energy because of the cheap and plentiful supply of oil. At present, governments and the public have no incentive to consider alternative forms of energy, and protecting the environment is not a high priority in the region. The government and people of Iraq are not fully aware of the importance of renewable energy, and therefore, the development of related technology within the region is primarily the result of each initiative and non-governmental organizations. Although there is an abundance of fossil fuels in Iraq, energy shortages began in 1991 because of the disruption caused by the full-scale destruction of the country. The obvious renewable energy resource available in Iraq is the solar energy, and its exploitation would give a means to reduce $\mathrm{CO}_{2}$ emissions from the burning of fossil fuels. Solar energy is becoming increasingly important because of the climatic change in the form of global warming. The $233 \mathrm{PW}$ of solar energy that reaches the surface of the earth annually is plentiful compared with the $24 \mathrm{TW}$ of the average annual power consumption by human activities. Global deserts receive more energy from the sun than is consumed annually by the world's population. The desert in Western Iraq has the greatest solar electricity generation capacity $1776 \mathrm{MJ} / \mathrm{m}^{2}(492333 \mathrm{kWh})$ of all the regional deserts. Iraqi deserts alone generate a mean power density of $3140-3373 \mathrm{MJ} / \mathrm{m}^{2}$, 
$(872222-937000 \mathrm{kWh})$ reaching a peak power density of $26860 \mathrm{MJ} / \mathrm{m}^{2} / \mathrm{year}$ according to the German Aerospace Center [6]. This gives Iraq the potential to stay a world energy supplier in the future but reliant on solar power not on fossil fuels. The continued progress and development of societies and the need to give conditions of comfort, both in housing and transport, have greatly increased global energy demand. Rising demand for energy caused an increase in fossil fuel consumption, which is expected to be depleted soon as shown in Figure 1.
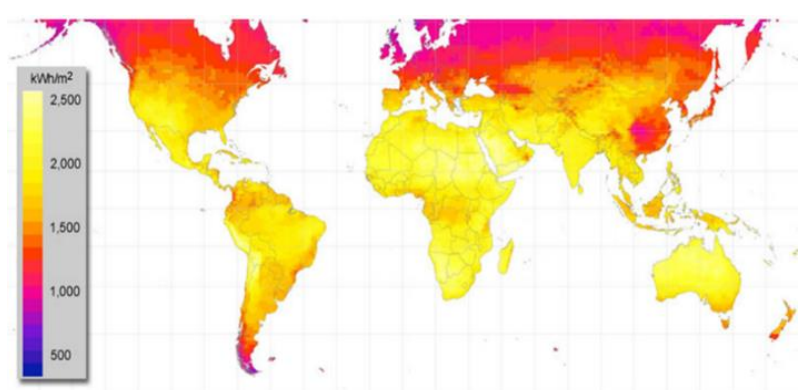

Figure 1. Iraq location at global irradiance $\left(1850-2300 \mathrm{kwh} / \mathrm{m}^{2}\right)$

The trend towards renewable energies are growing around the world in an impressive way. The production of electricity using solar energy has become available and an acceptable option around the world. A photovoltaic (PV) system utilizes a solar cell for converting the solar energy to electricity with depends on the photoelectric effect. PV system basically is a cell which may be classified as monocrystalline, poly-crystalline, organic cell, amorphous, and Nano-PV cells. Now the technology of PV can be used in various applications like plants of solar power, PV grid-connected, home-produced usage, power communication, satellites, and currently aircrafts as well as electric vehicle applications [7]. In Iraq solar energy can be considered the best and most logical alternative to burning fossil fuels. The solar energy falling to the ground in one hour is enough for a full year of electricity to all the earth if used properly. There is no denying that energy availability is important in the progress and development of societies. It also provides solutions to other dilemmas such as water, food, environment, health, education, climate protection, information, communication and mobility. An enough amount of environmentally friendly energy that reduces high air pollution and reduces greenhouse gases is one of the biggest challenges facing the planet today. Solar energy can be used in many applications and not fossil fuels. It can be used to heat the water in the residential buildings and factories. This energy can also be used to heat the air for home and laboratory heating purposes. It is also now used to heat the Trombe walls to store heat for ventilation and heating for the comfort purposed in houses and buildings. One of the most promising applications for the use of solar energy is water distillation. The most important applications of solar energy today are in the production of electricity and either by concentrated heating or using photovoltaic cells. Solar heat is used to heat the air that rotates wind turbines in solar chimney systems, as it is used in concentrated power plants to generate electricity. As for the solar cells, part of this fallen radiation is used in the production of electricity, while the largest part goes to heat the cell. Today, the use of photovoltaic thermal (PV/T) systems is an excellent, realistic, and promising alternative. In these systems, the photovoltaic cell is cooled using a cooling fluid, whether air, water or kinds of nanofluids, to increase its electrical output and to use the heat absorbed in other applications [8].

The crystalline solar cells have many advantages. They are efficient, reliable with long lifetime and have a long record of proven durability. Therefore, they are often the preferred solution for solar-based electricity production on buildings. On the other hand, thin-film solar panels are less efficient and have a shorter lifetime. However, thin-film technology is increasingly used in small applications. It is generally expected that in the long term, thin-film technology with multi-layer cells will be widely used and attain efficiencies beyond $25 \%$. The major advantage of thin-film is that they use less material and are therefore potentially less expensive than conventional PV technology. The use of PV technology to produce electricity has become known and popularly accepted these days. Photovoltaic systems are used outside or connected to the electrical grid (producing electricity directly to the network system). Photovoltaic cells outside the grid are used in small power systems linked to diesel power generators as an alternative to dust storms or clouds. Both these types of PV systems can be used in Iraq. Solar photovoltaic technology is suitable for generating electricity in rural desert areas away from the grid in particular. Iraq is rich in solar resources and when using hybrid solar power plants and diesel generators in remote logic, it can reduce fossil fuel discharges to a large extent. 


\section{SOLAR PANEL EFFICIENCY}

Solar panel efficiency is the measure of the quantity of solar energy which falls on the panel surface and is transformed into electricity. Due to the many advances in solar cell technology over the last 4-5 year the average solar panel efficiency has increased substantially from around $15 \%$ to almost $22 \%$. This increase in efficiency has increased the rated power output of standard size solar panels from $250 \mathrm{~W}$ up to $330 \mathrm{~W}$ or higher. Solar panel efficiency is specified by two main factors:

The cell efficiency is specified by the silicon cell structure and base silicon material used which generally either P-type or N-type. The cell efficiency is specified by what is known as the fill factor (FF) which is the optimum conversion efficiency of the cell.

The panel efficiency is specified by the total panel size, cell style and panel design. This is based on the number and type of cells used, the busbar design and interconnection of the cells. Learn more about the different panel types and latest solar cell technology [9].

Efficiency does make a big difference is in the total of roof area required. Higher efficiency panels require less area which is perfect where roof space is limited and can also allow larger capacity systems to be fitted to any roof. For example12 x high efficiency $360 \mathrm{~W}$ solar panels such as those from LG or Sunpower with a $21 \%$ conversion efficiency will provide up to $1100 \mathrm{~W}$ more total solar capacity than the same number of lower efficiency $270 \mathrm{~W}$ panels.

In real world use solar panel efficiency is also dependent on a number of external factors including panel orientation, location, time of year, shading, dirt and cell temperature. A standard size 60 cell (1m x $1.6 \mathrm{~m})$ panel with $17-19 \%$ efficiency typically has a power rating of 290-310 Watts where as a panel with higher efficiency of the same size can produce up to $330 \mathrm{~W}$. The most efficient panels explained in more detail below use extremely efficient $\mathrm{N}$-type IBC or Interdigitated Back Contact cells which can achieve up to $22 \%$ efficiency and generate an impressive 370 Watts [10]. Efficiency of different silicon solar cell types:

- $\quad$ Polycrystalline - 15 to $18 \%$

- Monocrystalline - 16.5 to $19 \%$

- $\quad$ Polycrystalline PERC - 17 to $19.5 \%$

- $\quad$ Monocrystalline PERC - 17.5 to $20 \%$

- $\quad$ Monocrystalline N-type - 19.5 to $20.5 \%$

- Monocrystalline N-type IBC - 20 to $22 \%$

Figure 2 shows the most efficient solar panels in the world.

\begin{tabular}{|c|c|c|c|c|}
\hline Manufacturer & Model & Size (W) & Cell Type & Efficiency \% \\
\hline SUNPOWER & $\times 22$ & $360 w$ & N-type IBC & 22 \\
\hline (ㄷ) LG & Neon $\mathrm{R}$ & $370 w$ & $\mathrm{~N}$-type IBC & 21.4 \\
\hline SUNPOWER & E2O & $327 \mathrm{~W}$ & $\mathrm{~N}$-type IBC & 20.1 \\
\hline (1) REC & N-Peak & 330w & P-Type Mono Half-cut & 19.8 \\
\hline (ㄷ) LG & Neon 2 & $335 \mathrm{~W}$ & N-type Mono & 19.6 \\
\hline QCELLS & Q.Peak Duo & $325 w$ & P-Type Mono Half-cut & 19.6 \\
\hline - WINAICO & WSP-MX & $330 \mathrm{w}$ & P-Type Mono PERC & 19.4 \\
\hline JASOLAR & JAM60503 & $320 \mathrm{w}$ & P-Type Mono Half-cut & 19.2 \\
\hline $\begin{array}{l}\text { Sumec } \\
\text { Phono' Solar }\end{array}$ & Twin Plus & $320 \mathrm{w}$ & P-Type Mono Half-cut & 19.2 \\
\hline Jinkó & Eagle 60M & $315 \mathrm{~W}$ & P-Type Mono PERC & 19.2 \\
\hline Trinasolar & Honey M Plus & $315 w$ & P-Type Mono PERC & 19.2 \\
\hline LONGi Solar & LR6-60PD & $315 \mathrm{~W}$ & P-Type Mono PERC & 19 \\
\hline
\end{tabular}

Figure 2. The most efficient solar panels in the world

\section{SOLAR DENSITY IN IRAQI DESERT}

PV electricity can be considered as the main alternative and the most possible application of solar energy. That solar energy is energy available everywhere and free of pollutants and a true friend of the environment, as the end is not subject to geographical or political restrictions and does not cause consumption of any fuel. At the same time, building the photovoltaic system requires short construction periods, small or medium size design systems can also be provided, so the design size of the PV plant is 
flexible and can be used directly and can be easily stored or redeployed in other areas. Photovoltaic systems can be joined with buildings. The study of the feasibility of solar energy in Iraq (current and future situation) requires us to discuss the following points: the status of energy in Iraq, the solar density in Iraqi desert; the benefits of using solar energy in Iraq. Iraq is a region rich in solar energy, where the sun's brightness increases more than 3300 hours a year as shown in Figure 3. The solar radiation falling in the desert areas of Iraq, which now accounts for more than $60 \%$ of the country's area. $437072 \mathrm{~km}^{2}$ is equal to hundreds of thousands of times the total energy generated in this country.

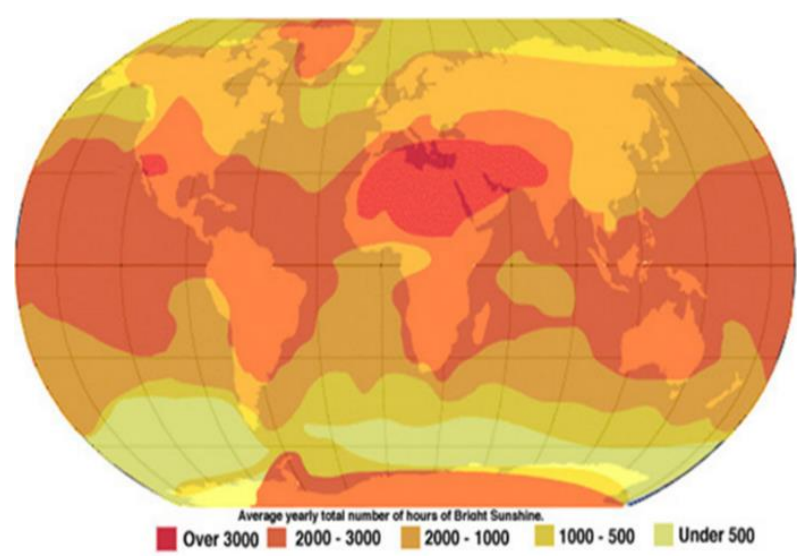

Figure 3. Average yearly total numbers of hours of bright sunshine

Iraq has a high-density solar card available across the country from north to south. The occurrence of this country in the Middle East, on the north-eastern edge of the Arabian Peninsula, is adjoining the region of the solar system. The climate in this country is very hot, with temperatures reaching 56 degrees Celsius during the hot summer from the beginning of May to the end of September. The climate in Iraq is generally dry (the rainfall is very small and in small amounts) and the atmosphere is very high. But the weather is humid in the southern coastal area of Basra province, the most popular days of the year. Air conditions such as the heat of the atmosphere associated with high solar radiation, humidity and dust, as well as lack of rain, can be considered as barriers to reducing the use of photovoltaic systems.

Desert areas in Iraq as shown in Figure 4, it's about to $220000 \mathrm{~km}^{2}$ and especially near the Saudi Arabian Empty Quarter, are areas of high solar density. The entire area of Iraq can be considered to have a suitable solar intensity for the operation of photovoltaic stations. The solar density of Iraq is approaching the density of the solar belt states, which are considered one of the highest solar densities in the world. According to the Iraqi studies [11], solar energy in Iraq has the ability to provide enough electricity to meet all the needs of local electricity in addition to the provision of significant quantities of electricity for export.



Figure 4. Considered Iraqi desert areas 
We calculate the energy that can be produced for each region according to the following equation $[12,13]$ :

$$
\mathrm{E}=\mathrm{A} \cdot \mathrm{r} \cdot \mathrm{H} \cdot \mathrm{PR}
$$

Where E - energy, kWh; A - total solar panel area, $\mathrm{m}^{2} ; \mathrm{r}$ - solar panel yield (\%) $\eta(15 \%$ to $24 \%)$; $\mathrm{H}$ - annual average irradiation on tilted panels (shadings not included), $\mathrm{kWh} / \mathrm{m}^{2}$.an; $\mathrm{PR}$ - performance ratio, coefficient for losses (range between 0.9 and 0.5 , default value $=0.75$ ).

Losses details (depend of site, technology, and sizing of the system):

- $\quad$ Inverter losses $(6-15 \%)$

$8 \%$

Température losses $(5-15 \%)$

$8 \%$

DC cables losses (1-3\%)

$2 \%$

$2 \%$

$3 \%$

$3 \%$

$2 \%$

$0 \%$

The first region is located between the provinces of Anbar and Karbala estimated at about 130000 $\mathrm{km}^{2}$ (Bottom-left: Latitude 31.9831, Longitude 39.1303, Upper-right: Latitude 33.5168, Longitude 42.9096).

Table 1. Solar radiation falling at first region at $2017, \mathrm{kWh} / \mathrm{m}^{2}$ [14]

\begin{tabular}{|c|c|c|c|c|c|c|c|c|c|c|c|c|c|c|}
\hline Lat & Lon & Jan & Feb & Mar & Apr & May & Jun & Jul & Aug & Sep & Oct & Nov & Dec & Ann \\
\hline 31.75 & 39.25 & 3.52 & 4.86 & 5.69 & 6.67 & 7.78 & 8.52 & 7.91 & 7.56 & 6.48 & 5.24 & 3.91 & 3.22 & 5.96 \\
\hline 31.75 & 41.75 & 3.5 & 4.81 & 5.46 & 6.36 & 7.74 & 8.43 & 8 & 7.43 & 6.42 & 5.11 & 3.8 & 3.2 & 5.86 \\
\hline 31.75 & 42.25 & 3.51 & 4.69 & 5.41 & 6.12 & 7.51 & 8.34 & 7.88 & 7.33 & 6.37 & 5.01 & 3.67 & 3.22 & 5.76 \\
\hline 32.25 & 39.75 & 3.46 & 4.52 & 5.52 & 6.44 & 7.86 & 8.52 & 8.06 & 7.56 & 6.36 & 5.09 & 3.73 & 2.94 & 5.85 \\
\hline
\end{tabular}

Using previous (1) and all the required data, we can say that the value of energy available during one year is: $31424 \mathrm{PWh} /$ year.

The second region is located between the provinces of the Najaf, Diwaniyah and Samawa estimated at about $70000 \mathrm{~km}^{2}$ (Bottom-left: Latitude 29.1481, Longitude 43.7570, Upper-right: Latitude 31.7429, Longitude 45.9542).

Table 2. Solar radiation falling at second region at $2017, \mathrm{kwh} / \mathrm{m}^{2}$ [14]

\begin{tabular}{lllllllllllllll}
\hline Lat & Lon & Jan & Feb & Mar & Apr & May & Jun & Jul & Aug & Sep & Oct & Nov & Dec & Ann \\
\hline 29.25 & 43.75 & 3.79 & 5 & 5.72 & 6.43 & 7.13 & 8.31 & 7.84 & 7.3 & 6.57 & 5.3 & 3.95 & 3.65 & 5.92 \\
29.75 & 45.75 & 3.73 & 4.65 & 5.44 & 6.15 & 6.95 & 8.17 & 7.77 & 7.2 & 6.55 & 5.28 & 3.87 & 3.52 & 5.77 \\
30.25 & 43.75 & 3.63 & 4.88 & 5.56 & 6.27 & 7.34 & 8.3 & 7.77 & 7.31 & 6.45 & 5.15 & 3.7 & 3.46 & 5.82 \\
30.75 & 45.75 & 3.46 & 4.56 & 5.34 & 5.98 & 6.85 & 8.13 & 7.66 & 7.14 & 6.42 & 5.07 & 3.55 & 3.33 & 5.62 \\
31.25 & 43.75 & 3.44 & 4.6 & 5.31 & 6 & 7.36 & 8.27 & 7.75 & 7.29 & 6.32 & 4.94 & 3.51 & 3.19 & 5.66 \\
31.75 & 45.75 & 3.2 & 4.34 & 5.15 & 5.58 & 6.65 & 7.93 & 7.37 & 7.02 & 6.2 & 4.79 & 3.25 & 3.04 & 5.38 \\
\hline
\end{tabular}

By using the (1) and all the required data, we can say that the value of energy available during the year is: $15741 \mathrm{PWh} /$ year.

The third region is located between the provinces of Nasiriyah and Basra, estimated about 30000 $\mathrm{km}^{2}$ (Bottom-left: Latitude 30.0621, Longitude 46.1469, Upper-right: Latitude 31.1965, Longitude 48.1025).

Table 3. Solar radiation falling at third region at 2017, $\mathrm{kwh} / \mathrm{m}^{2}$ [14]

\begin{tabular}{|c|c|c|c|c|c|c|c|c|c|c|c|c|c|c|}
\hline Lat & Lon & Jan & Feb & Mar & Apr & May & Jun & Jul & Aug & Sep & Oct & Nov & Dec & Ann \\
\hline 30.25 & 46.25 & 3.54 & 4.42 & 5.22 & 6.02 & 6.99 & 7.97 & 7.53 & 7.07 & 6.36 & 5.04 & 3.52 & 3.29 & 5.57 \\
\hline 30.25 & 47.25 & 3.44 & 4.12 & 5.06 & 5.86 & 6.96 & 7.91 & 7.37 & 7 & 6.31 & 4.99 & 3.52 & 3.21 & 5.47 \\
\hline 30.25 & 48.25 & 3.27 & 4.16 & 5.02 & 5.67 & 6.95 & 7.87 & 7.28 & 6.9 & 6.28 & 4.98 & 3.52 & 3.14 & 5.41 \\
\hline 31.25 & 46.75 & 3.18 & 4.24 & 5.05 & 5.67 & 6.74 & 7.87 & 7.31 & 6.94 & 6.19 & 4.83 & 3.22 & 3.03 & 5.35 \\
\hline 31.25 & 47.25 & 3.13 & 4.13 & 5.06 & 5.61 & 6.9 & 7.82 & 7.2 & 6.87 & 6.16 & 4.85 & 3.31 & 3.01 & 5.33 \\
\hline 31.25 & 48.25 & 3.14 & 4.14 & 5.09 & 5.68 & 7.01 & 7.94 & 7.27 & 6.63 & 6.19 & 4.94 & 3.41 & 3.09 & 5.37 \\
\hline
\end{tabular}


By using the (1) and all the required data, we can say that the value of energy available during the year is: $6240 \mathrm{PWh} /$ year.

When the output of the three regions is collected, the output is as follows:

$$
\begin{aligned}
& \mathrm{E}_{\mathrm{T}}=\mathrm{E}_{1}+\mathrm{E}_{2}+\mathrm{E}_{3} \\
& \mathrm{E}_{\mathrm{T}}=31424+15741+6240=53405 \mathrm{PWh} / \text { year. }
\end{aligned}
$$

It is clear from (2) that it is possible to produce a very large quantity of electricity enough to cover not only Iraq's electricity needs (215 PWh/year), but also to cover the need of some neighboring countries by exporting electricity. Where the need for Iraq represents the percentage of electricity during one year compared with the quantity produced from the exploitation of the desert is about $(0.4 \%)$ from the total production $53405 \mathrm{PWh}$ year.

$$
\frac{215 \mathrm{PWh} / \text { year }}{53405 \mathrm{PWh} / \text { year }} * 100 \%=0.4 \%
$$

\section{CONCLUSION}

The using of solar energy in Iraq to generate electricity offers many benefits. Solar energy is an environmentally friendly energy: it is clean and sustainable and helps to protect its environment and reduce the damage caused by the production of electricity from fossil fuels. The use of solar energy will certainly reduce air pollution, as it will reduce the emissions of sulfur oxides, nitrogen oxides, carbon monoxide and partially burned hydrocarbons and reduce the emission of the first greenhouse gas (carbon dioxide) in the atmosphere. Solar energy is free energy, which gives it economic advantages; there is no need to spend money to buy fuel or to reduce the damage produced from using it.

The reliance on solar energy to produce electricity will reduce the dependence of the Iraqi state on non-renewable sources. Solar systems do not require much maintenance and the highest costs are spent on the installation costs, so there are no recurring costs at all. We have some successful projects in the provinces of Najaf and Karbala, where solar power plants that do not exceed $400 \mathrm{~kW}$ have been constructed and are used to secure the electricity needed to draw water from the artesian wells and pump them back to the nearby palm groves located in the Najaf desert district. Through these projects, desert lands were reclaimed to farms and pastures that can be used for agricultural products, animal husbandry and preservation of the environment and soil.

\section{REFERENCES}

[1] Al-Waeli Ali A. K., Al-Asadi Kadhem A. N., "Analysis of Stand-Alone Solar Photovoltaic for Desert in Iraq," International Research Journal of Advanced Engineering and Science, vol. 3, no. 2, pp. 204-209, 2018.

[2] Iraq, The Iraqi Ministry of Electricity, [Online]. Available: [https://moelc.gov.iq/] .

[3] Nur Farhana Mohd Razali, Ahmad Fudholi, Mohd Hafidz Ruslan, Kamaruzzaman Sopian, "Experiment study of water based photovoltaic-thermal (PV/T) collector," International Journal of Electrical and Computer Engineering (IJECE), vol. 9, no. 1, pp. 118-125, Feb 2019.

[4] International hydropower associon, [Online]. Available: https://www.hydropower.org/.

[5] Green group, [Online]. Available: http://www.greenkogroup.com/about.php.

[6] Al-Douri Y., Abed Fayadh M., "Solar Energy Status in Iraq," Journal of Renewable and Sustainable Energy, vol. 8, 2016.

[7] Adnan Hussein Ali, Hassan Salman Hamad, Ali Abdulwahhab Abdulrazzaq, "Performance Investigation of Grid Connected Photovoltaic System Modelling Based on MATLAB Simulation," International Journal of Electrical and Computer Engineering (IJECE), vol. 8, no. 6, pp. 4847-4854, Dec 2018.

[8] Chaichan M. T., Kazem H. A., Mahdy A. M. J., Al-Waeely A. A., "Optimal Sizing of a Hybrid System of Renewable Energy for Lighting Street in Salalah-Oman using Homer Software," International Journal of Scientific Engineering and Applied Science (IJSEAS), vol. 2, no. 5, pp. 157-164, 2016.

[9] Clean energy reviews, [Online]. Available: https://www.cleanenergyreviews.info/.

[10] SunPower company, [Online]. Available: https://us.sunpower.com/.

[11] Iraq, Ministry of Higher Education and Scientific Research, [Online]. Available: http://mohesr.gov.iq/ar/.

[12] Professional site of solar PV energy and Photovoltaic software, [Online]. Available: https://photovoltaicsoftware.com/.

[13] PV watts calculator, [Online]. Available: https://pvwatts.nrel.gov.

[14] Solar and meteorological data sets from NASA research for support of renewable energy, building energy efficiency and agricultural needs, [Online]. Available: https://power.larc.nasa.gov/data-access-viewer. 


\section{BIOGRAPHIES OF AUTHORS}

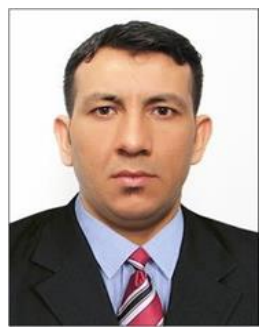

Ahmed Zkear Abass Al-myahi, PhD student in the Department of Industrial Power Supply Systems at the university Novosibirsk State Technical University, 20, Prospekt K. Marksa, Novosibirsk, 630073, Russia. Email: theking.amir@ mail.ru

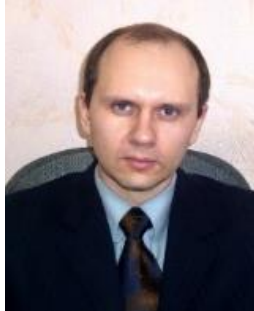

Dmitry A. Pavlyuchenko, Novosibirsk State Technical University, Department of Power Supply Systems, Ph.D., Associate Professor, Head of Department. Main directions of investigations: enhancement of energy efficiency, operating performance and development of power supply systems. E-mail: pavlyuchenko@ copr.nstu.ru 